\title{
Halal Tourism Concepts and Policies: Case in West Nusa Tenggara
}

\author{
Muchamad Zaenuri ${ }^{1, *}$ Yusuf A. Hasan ${ }^{2}$ Sri Handari Wahyuningsih ${ }^{3}$ Muhammad Eko \\ Atmojo $^{4}$ Muhammad Iqbal ${ }^{5}$
}

${ }^{1}$ Department of Government Affairs and Administration Universitas Muhammadiyah Yogyakarta, Indonesia

${ }^{2}$ Department of Islamic Education Universitas Muhammadiyah Yogyakarta, Indonesia

${ }^{3}$ Department of Management Universitas Muhammadiyah Yogyakarta, Indonesia

${ }^{4}$ Department of Government Affairs and Administration Universitas Muhammadiyah Yogyakarta, Indonesia

${ }^{5}$ Department of Political Science National Cheng Kung University, Tainan, Taiwan

*Email: muchamadzaenuri@umy.ac.id

\begin{abstract}
Halal tourism has outstanding potential and prospects in Indonesia, and this is because most of the population is Muslim, and there are also very many religious tourist destinations. Besides that, the tourism industry in Indonesia is very enthusiastic about welcoming this halal tourism phenomenon, which is then supported by the Government by establishing three provinces, namely Aceh, West Sumatra and West Nusa Tenggara (NTB) as halal tourist destinations. Such excitement still leaves problems both in terms of terminology and conceptual about halal tourism. Likewise, in the community, there are still disagreements about what is meant by halal tourism and whether the Government can play a more active role in this halal tourism. Of these various problems, this study seeks to find alternative solutions to help provide conceptual recommendations for both the Government and the private sector so that they can synergize in developing halal tourism governance in the regions. Based on the research problem, the objectives to be achieved are: 1) understanding the various governance concepts that can be applied to halal tourism governance in Indonesia, and 2) knowing the government policies that have been carried out on halal tourism. The research method used is qualitative, this method is used to understand the concept of halal tourism and the application of halal tourism policies in NTB Province as one of the provinces that already have a halal tourism policy. Data collection was carried out through documentation, interviews, and observations to various stakeholders. By using this method, various findings were obtained, including that the concept of halal tourism emphasizes more on food, while for facilities and facilities the term sharia is used. The implementation of the halal tourism policy in NTB on the provision of accommodation facilities has various features. Some accommodation providers include sharia labels and some do not contain sharia labels but work on sharia grounds. Policy implementation is not fully enforced because it is still at a process level.
\end{abstract}

Keywords: Halal Tourism, Management, West Nusa Tenggara

\section{BACKGROUND}

Indonesia, as a country with the largest Muslim population in the world, has the potential to develop halal tourism. Moreover, in the current era, the global tourism industry is also growing and has tremendous potential. The potential for developing the halal tourism industry can be seen from the development of the contribution of the Muslim community to tourism in various countries where the tourism objects visited are not Muslim. Thomson Reuters \& Dinar Standard in 2012 stated that the contribution of the tourism market in the world came from the Muslim community, namely in the range of USD 137 billion or around $12.50 \%$ of the total world tourism expenditure [1]. When viewed from the market segment, which reaches $12.50 \%$, it can be said that halal tourism is a very profitable business. Countries such as South Korea, Thailand, and even Singapore are also enthusiastically working on this halal tourism. 
As a business activity, halal tourism also experiences tough competition. The Assistant Deputy conveyed this for Market Segment Development for Business and Government, Ministry of Tourism as conveyed at the Republican Conference held by the Daily Republika with the Provincial Government of West Nusa Tenggara (NTB). This competition with many countries, especially the member countries of the Islamic Cooperation Organization (OIC) and ASEAN countries, if Indonesia cannot win the feeling, these countries will certainly take it [2].

Indonesia is a country that has great potential to develop halal tourism. The government has issued various regulations on facilitation and dissemination of information about everything about halal tourism so that the public can better understand it. Even though the government has planned to develop halal tourism, there are still differences in perceptions in accepting this halal tourism. Using the term sharia tourism creates a connotation that there is a religious mission in it, as was feared by the Governor of Bali Mangku Pastika [3].

In the Indonesian context, every region has tried to apply the principles of halal tourism. Still, formally the government has only designated 3 (three) provinces as halal tourism destinations, namely West Sumatra, Aceh and NTB. Especially for the Province of NTB, especially on the island of Lombok, it has received an award as the best halal tourist destination in the world according to the 2015 World Halal Travel Awards in Abu Dhabi. As the best halal destination in the world, of course, it is not an instantaneous result, but it has gone through a long process, starting from its first pioneering in 2010 .

From these two areas, there are quite exciting problems, NTB which is determined by the government as a halal tourist destination. Apparently, there are still many complaints from tourists, there is still a lack of Islamic nuances in lodging, and there is still a lack of cleanliness, especially in the disposal of garbage and waste. Further development as a business activity turns out that halal tourism cannot be carried out only by the participation of the tourism industry, but also involves other stakeholders who participate in the management of halal tourism. The role of the government as a regulator is, of course, significant.

\section{LITERATURE REVIEW}

The beginning of the management concept was put forward to solve problems that occurred in western capitalistic countries. F.W. Taylor as the main initiator of scientific management (scientific management) is also to increase productivity and work efficiency for factory workers in the capitalistic western world [4]. Then criticized by [5] because it is considered to be very exploiting of labour, the failure of scientific management because it is based on the assumption about human nature, that humans are rational. Their primary motivation is to meet their economic and physical needs. This basic concept is very contrary to the Islamic concept, which rewards humans that work is a religious command and has the value of worship. Likewise, in the world of the tourism industry, the principles of tourism management are still capitalistic [6]. From the various gaps in the concept, it is necessary to develop alternative Islamic tourism by calling halal tourism.

The concept of halal tourism can be traced from the provisions in the Holy Qur'an as the primary source of normative concepts. Most Muslim countries tend to interpret tourism based on the provisions in the Qur'an, so it is not wrong if many experts call this halal tour as Islamic tourism. The following is a form of tourism based on the Al-Qur'an.

a. Hijja (ةجح) involves travelling and pilgrimage to Mecca. This trip is a requirement for every healthy adult Muslim. At least once in a lifetime to perform Hajj.

b. Zejara (يز مرا) refers to visits to other holy places.

c. Rihla (حر ثة) is travel for other reasons, such as education and commerce.

The emphasis is on directional movement, as a component of a spiritual journey in God's service. Shari'ah (لا لا برش (لع) the law determines what is acceptable - halal ( $(\tau)$ ), and what is not accepted haram (مارح) in everyday life and during travel [7].

Besides the term Islamic tourism, halal tourism is also conceptualized as sharia tourism. The concept of Sharia tourism is a process of integrating natural values into all aspects of tourism activities. The value of Islamic law as a belief and belief held by Muslims is a primary reference in building tourism activities. Sharia tourism considers the fundamental values of Muslims in its presentation, from accommodation, restaurants, to tourism activities which always refer to the norms of nature [7].

The concept of Sharia tourism is the actualization of the concept of Islam, where the value of halal and haram is the primary measure. This means that all aspects of tourism activities cannot be separated from halal certification, which must be a reference for every tourism actor [8]. The concept of Sharia tourism can also be interpreted as tourism activities based on worship and da'wah when Muslim tourists can travel and admire the results of Allah SWT's creation (tafakur alam) by continuing to carry out the obligatory prayer obligations five times a day, and all of this is well facilitated and stay away from everything. Which was prohibited by Him [9]. 
The basis of Sharia tourism, of course, is an understanding of the meaning of halal in all aspects of tourism activities ranging from hotels, transportation facilities, food and beverage facilities, the financial system, to the facilities and tourism service providers themselves. For example, a Sharia hotel will not accept a guest partner who will stay overnight if the guest is a partner who is not a muhrim (unable to show a marriage certificate). Besides, hotels that carry the Sharia concept will certainly not sell alcoholic drinks and foods containing pork which is prohibited in Islam. Besides, the selection of tourist destinations that are following the values of Islamic Sharia is also a significant consideration in applying the concept of Sharia tourism. Each tourist destination to be addressed must be following the values of the island, such as having adequate mosque and prayer facilities, no place for activities. Night entertainment and prostitution, as well as the community, supports the implementation of Islamic Sharia values, such as the absence of gambling, cockfighting or rituals that are contrary to Islamic teachings. One thing that must be understood is that Sharia tourism does not have to be religious tourism which is generally valid today [7].

Furthermore, [10] identifies various definitions of Islamic tourism as follows:

Table 1. Definition of Islamic Tourism

\begin{tabular}{|c|c|}
\hline AUTHORS & DEFINITION \\
\hline Henderson [11] & $\begin{array}{l}\text { All product development and marketing efforts are designed and aimed at Muslims. } \\
\text { Tourism motivation is not always or entirely religious. Tourists can seek recreational } \\
\text { experiences similar to those of non-Muslims, even though the parameters are set Islamic. } \\
\text { Location t Objective travel is not necessarily the location where sharia or Islamic law in } \\
\text { full force in the country. }\end{array}$ \\
\hline $\begin{array}{l}\text { Ala-Hamarrneh } \\
\text { [12] }\end{array}$ & $\begin{array}{l}\text { The economic concept for Islamic tourism is an extension and expansion oriented } \\
\text { concept that focuses on the importance of intra-Muslim and intra-Arab tourism in terms } \\
\text { of the entry of new tourist markets and tourist destinations. } \\
\text { The concept of culture for Islamic tourism includes a vision and ideas that outline the } \\
\text { inclusion of Islamic religious-cultural sites in the tourism program with "pedagogical" and } \\
\text { self-confidence building elements. } \\
\text { The religion-conservative concept for Islamic tourism has not been theoretically } \\
\text { articulated. But various opinions and comments in discussions about the future of tourism } \\
\text { in the Arab and Islamic world as well as some hotel management practices suggest that } \\
\text { articulation and implementation are only a matter of time. }\end{array}$ \\
\hline $\begin{array}{l}\text { Henderson } \\
{[13]}\end{array}$ & $\begin{array}{l}\text { Tourism is done by Muslims, although it can be extended to those whose non-Muslims to } \\
\text { be motivated to go to the people of Islam and took place in the Muslim world. }\end{array}$ \\
\hline Shakiry [14] & $\begin{array}{l}\text { The concept of Islamic tourism is not limited to religious tourism but extends to all forms } \\
\text { of tourism except those that go against Islamic values. }\end{array}$ \\
\hline Hassan [15] & $\begin{array}{l}\text { In a narrow sense, it can be said as "Religious Tourism", namely visiting holy places } \\
\text { throughout the Muslim world. But in a broad sense, it is a type of tourism that adheres to } \\
\text { Islamic values. Most of these values are shared with other religious and non-religious } \\
\text { beliefs (e.g. code of conduct promoted by the World Tourism Organization). It calls to } \\
\text { respect the local community and local environment, benefit residents, politeness and learn } \\
\text { about other cultures. }\end{array}$ \\
\hline
\end{tabular}




\begin{tabular}{|l|l|}
\hline \multicolumn{1}{|c|}{ AUTHORS } & \multicolumn{1}{c|}{ DEFINITION } \\
\hline Hassan [16] & $\begin{array}{l}\text { Islamic tourism means a new ethical dimension in the field of tourism, which is a } \\
\text { generally accepted value as a high standard of morality and decency. This is also to } \\
\text { respect local beliefs and traditions and care for the environment. This is a new outlook on } \\
\text { life and society. Islamic tourism brings back noble values amidst rampant consumerism } \\
\text { and all of them are available for use and abuse in the most selfish ways. It also encourages } \\
\text { understanding and dialogue between countries of different civilizations and efforts to } \\
\text { know about different peoples' backgrounds and heritage. }\end{array}$ \\
\hline Dogan [17] & $\begin{array}{l}\text { Islamic tourism includes Muslim tourism activities with the aim of the beach } \\
\text { for relaxation and entertainment in hotels that apply Islamic principles. }\end{array}$ \\
\hline
\end{tabular}

Source : [10]

From the various definitions, it can be concluded that halal tourism is a tourism activity that pays attention to Islamic values by obtaining products that are halal in their services. Halal tourism management means the efforts of tourism stakeholders to provide various halal facilities for tourists.

Studies on halal tourism in Indonesia mostly focus on the potential and marketing of halal tourist destinations. [18] conducted a study on the potential of the halal tourism market in Indonesia, obtaining results that the Middle East market occupies a significant position and it is necessary to carry out more intense promotion through various massive media. More specifically, [19] researched the Analysis of the Islamic Tourism Market in the City of Yogyakarta regarding the destination products, service quality and required attributes of Islamic tourism, indicating that the city of Yogyakarta has enormous market potential. The halal tourism market that is a mainstay of Yogyakarta is from various Middle Eastern countries and tourists from outside the island. Other research conducted in NTB regarding the promotion of halal tourism shows that in promotion there is a commodification of tourism that takes into account Islamic principles and values into a commodity that can have political nuances, namely the existence of government control over capital in the region [20].

Another more comprehensive study conducted by [22], this study is limited to examining the role of religion in the context of tourism. This study examines the moderate role of religion in the relationship between value and customer satisfaction. This study aims to test the effect of traditional values and Islamic religious values on consumer satisfaction in halal tourist destinations empirically. Besides, this study also analyzes the moderate role of religiosity in the relationship between Islamic values and customer satisfaction with halal objectives. The results clearly show that only traditional values have a significant and direct effect on customer satisfaction with halal objectives, while Islamic values have no significant effect on customer satisfaction. Islamic values, especially the non-physical attributes of Islam, significantly affect customer satisfaction only under the moderation of religiosity. Thus, the destination marketer must provide a very traditional value to create high customer satisfaction with a halal objective. Marketers should also consider non-physical Islamic attributes such as segregation of service delivery when they target consumers with high religiosity to attract more Muslim tourists.

Recent research on the potential and prospects of the halal tourism industry in Indonesia was carried out by [21], the results of this study indicate that the essence of halal tourism emphasizes the principles of sharia in tourism management and polite and friendly services for all tourists and the surrounding environment. Therefore, to realize Indonesia as a centre for world halal tourism, its development strategy is directed at fulfilling the tourism competitiveness index as its prominent indicators, including improving infrastructure, promotion, preparation of human resources, significantly increasing the capacity of tourism business actors.

\section{RESEARCH METHOD}

The object of study by specifying the Province of West Nusa Tenggara with the consideration that it has been designated as a halal tourism destination in Indonesia. This location is suitable as a research location because it is following the government's decision that the province of NTB is used as a tourist destination for sharia and also has firm Islamic cultural roots. The selection of the Grand Madani hotel was 
based on the consideration that the hotel had obtained halal certification from the MUI.

Determining the focus of research is closely related to the problems to be solved. Two specific purposes will be achieved in setting the focus, namely as a study limiter and to meet the inclusion-exclusion criteria or to include-issue new information obtained in the field [23]. Based on the research problems and objectives, this research will be carried out as carefully and thoroughly as possible.

Data collection techniques in this study used techniques, namely: 1) participant observation; Through this participatory observation, it is hoped that the researcher will learn the words and actions and meanings attached to the object being observed. Participation is carried out by researchers by staying and getting services from sharia and conventional hotels. This technique is used to obtain accurate data because the researcher is involved in the process and the operational dynamics of the hotel being observed; 2) Indepth Interview; This technique is fundamental to explore the process of sharia hotel business governance that leads to strengthening of Islamic tourism. However, it is realized that this technique requires cooperation and closeness with informants as well as a long time to ensure the certainty of the interview, with this technique it is hoped that it can dig more in-depth data on informants that are not revealed when using participant observation. Informants include leaders and staff of Islamic and conventional hotels, leaders and staff of tourism industry companies, chairmen and members of community groups and tourism consultants; and 3) Documentation; To obtain secondary data is mostly done through documentation, documents can be in the form of written data, images, or statistical data. Certain documents constitute explicit knowledge which is very useful for classification and analysis. The required documents concern policies, Islamic and conventional hotel governance documents, the number of visitors, and visitor characteristics.

As has been done by many researchers, in qualitative studies data collection and analysis are carried out simultaneously. By using qualitative data analysis, a comprehensive picture will be obtained about the implementation of sharia tourism policies in NTB Province and sharia tourism governance involving the government, private sector and the community.

\section{RESULT AND DISCUSSION}

From secondary data in the form of policies implemented by the NTB Provincial Government, it can be seen that policy regulations to regulate halal tourism in NTB are regional regulations and government regulations, both of which are issued sequentially. Besides that, primary data has also been displayed, which is collected through participant observation, where researchers become tourists and stay at halal tourist accommodation services. This is an illustration of the implementation of halal tourism in a hotel as a provider of halal tourist accommodation services, namely the Grand Madani hotel.

\subsection{Implementation of Halal Tourism in Accommodation Services}

There are several hotels declared by the local government as sharia hotels in NTB province to support halal tourism. One of the halal tourism actors who have declared themselves as sharia-based accommodation in NTB Province is the Lombok Raya Hotel and the Grand Madani Hotel.

\subsubsection{Bedroom Accommodation}

Grand Madani Hotel has designated it as a Sharia hotel, as a hotel that provides sharia-based services, the Grand Madani hotel provides rooms that suit the needs of Muslim tourists, room layout and choices of Islamic nuances of furniture. Bedrooms that provide comfort to Muslim tourists can be provided with various amenities, including

1. There is a floor allocated explicitly for women and families,

2. An indicator towards mecca (qibla) in the bedroom to determine the direction of prayer,

3. Prayer mats and al-quran is available in every bedroom,

4. Conservative television channels (no tv channels that are sexy), and

5. Non-figurative decoration patterns (not in the form of humans and animals).

At the Grand Madani hotel, floors are not explicitly allocated for women and families, but each floor is provided with space for chatting and with a comfortable atmosphere. As in the following picture:

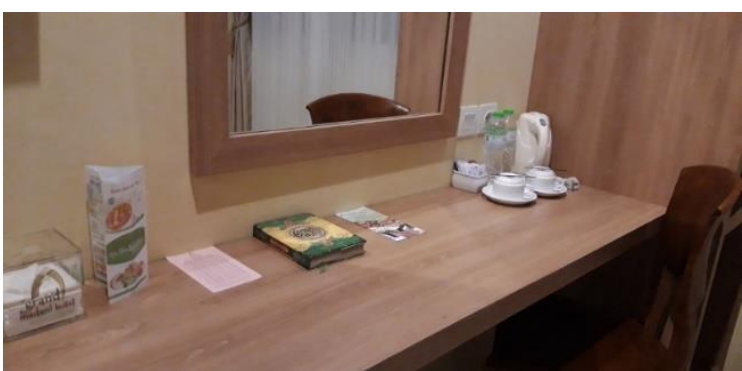

Figure 1. Al Qur'an Placed in the Deskroom

The placement of the Al Qur'an and the prayer mat in a particular place near the bed makes it easier for tourists to pray in the room. The prayer mat is clean and equipped with a sarong for men's prayers and mukenah for women. As shown below: 


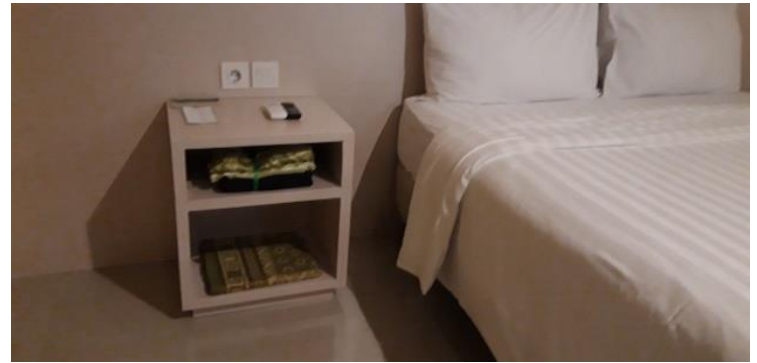

Figure 2. Prayer Equipment Place

TV shows are provided with three channels related to Islamic da'wah, two local stations from Lombok and one national channel. There are no violent TV shows. Besides religious channels, there is also a national tv channel that specializes in news tv. One of the look religious channels in the following image:

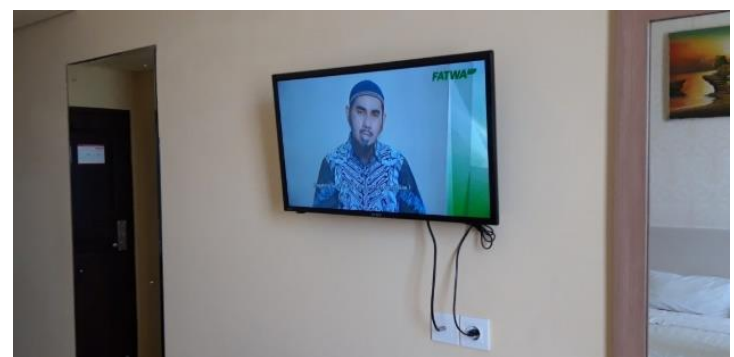

Figure 3. Shari'i Nuanced Television Shows

\subsubsection{Human Resources}

All human resources owned by the Grand Madani Hotel are Muslim, using Islamic clothing and attributes. For female employees, all wear jilbabs and dress not as obscene. Meanwhile, male employees wear sarongs and clothes typical of Lombok. As shown in the following picture:

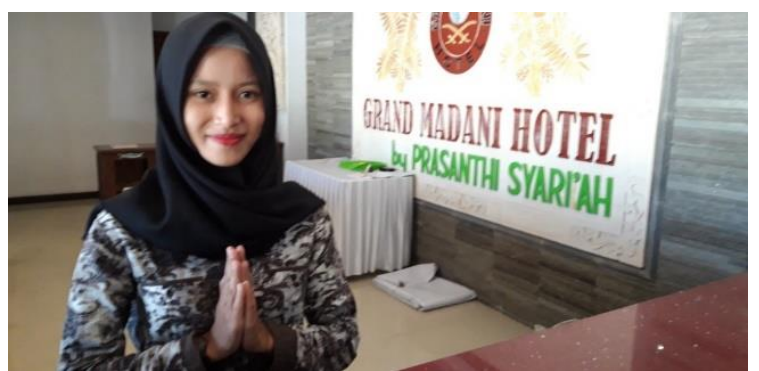

Figure 4. Friendly Welcome from Grand Madani Hotel Front Office Staff

A place for prayer in the form of a prayer room is prepared around the hotel building, and the place for ablution is neatly arranged. Every prayer time the call to prayer is always pronounced and is always used for congregational prayer.

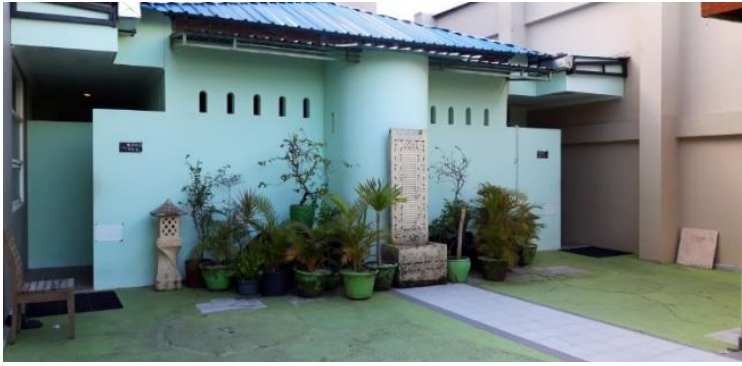

Figure 5. Wudhu Facilities

\subsubsection{Food Catering}

For food provision, halal food is always served; the restaurant always serves food that has been tested for its halalness. They have also legally obtained halal certification from the NTB MUI. The label is affixed to the glass door before entering the restaurant.

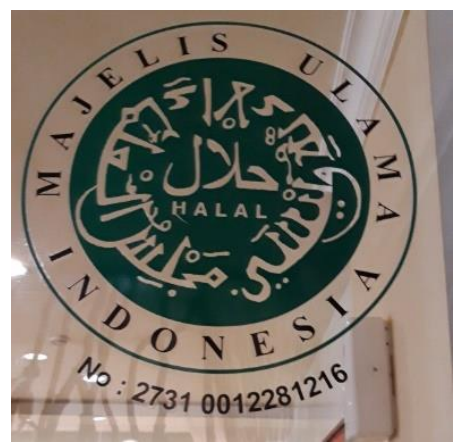

Figure 6. Halal Label on Restaurant Door

Officers serving guests in serving food are already wearing clothes that are following Islamic sharia, for women who already wear the hijab and behave politely and always say hello to visitors.

Most of the visitors are also Muslim people who wear clothes according to Islamic sharia. As shown in the following picture:

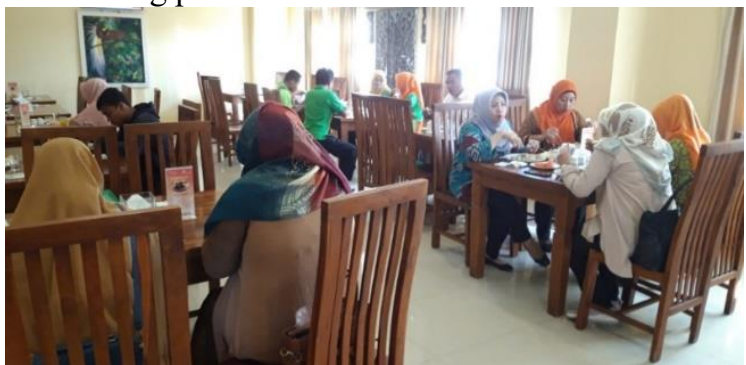

Figure 7. Restaurant Situation

\subsubsection{Aminities}

There is a prayer room which is used regularly and calls out the call to prayer every time it is praying. Many employees, especially men, pray in congregation in musholah, every prayer time there is always congregational prayer. 


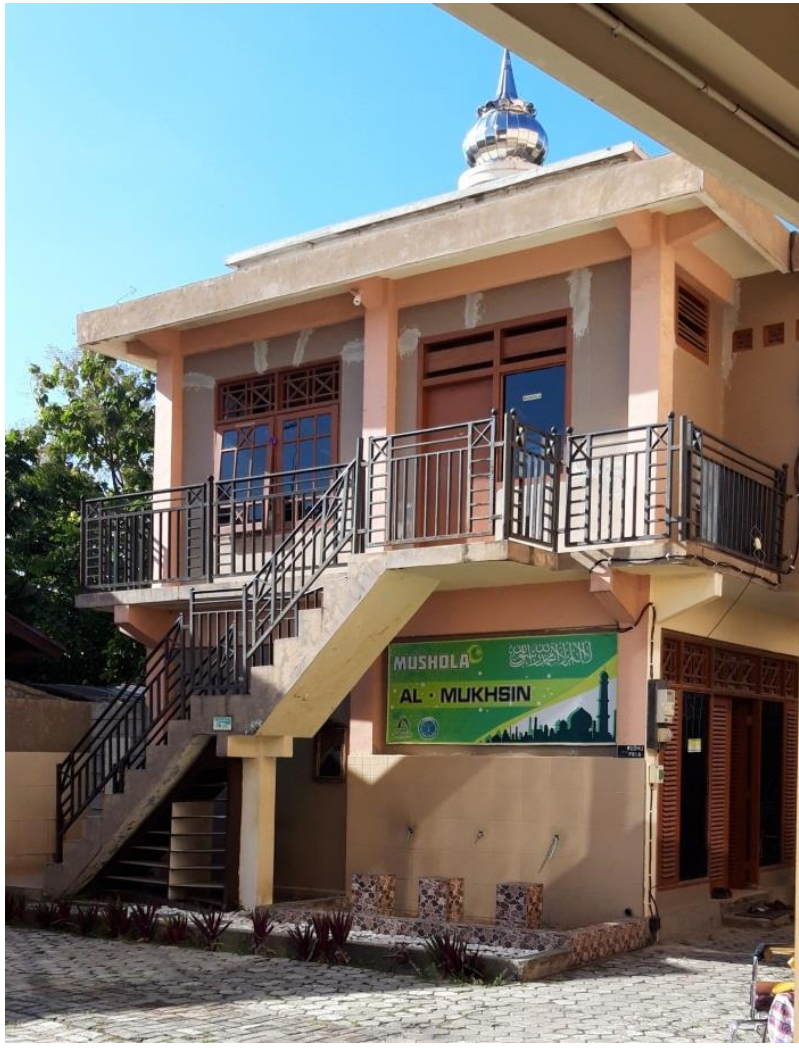

Figure 8. Mushala for Hotel Guests

Swimming pool facilities at the Grand Madani Hotel have a special pool for women. There are calls for wearing swimsuits following Islamic sharia and available swimsuits to borrow, especially for women.

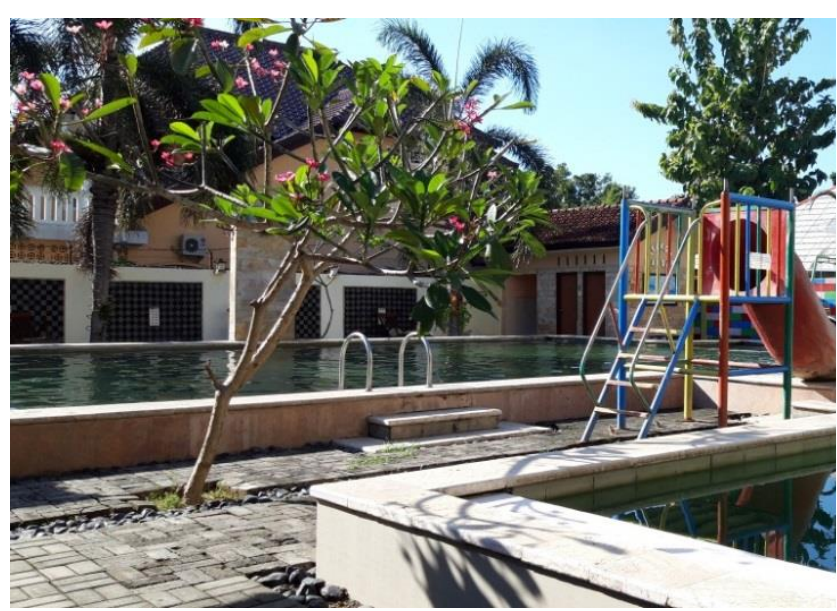

Figure 9. Separate Swimming Pool

\section{CONCLUSION}

In principle, Hotel Grand Madani has implemented Islamic values which refer to the concept of halal tourism itself. The concept that was built is the content of the hotel manager in order to present an alternative stay for tourists. Halal tourism-based governance in this hotel refers to the rules made by the East Nusa Tenggara provincial government. Hotel Grand Madani has also met the indicators of halal tourism regulated by the West Nusa Tenggara government.

\section{AUTHORS' CONTRIBUTIONS}

Muchamad Zaenuri: Conducting research with the literature review stage, collecting data and analyzing the data that has been collected. The author also plays an active role in making journal article manuscripts starting from the background, literature review to narrating data.

Yusuf A. Hasan, Sri Handari Wahyuningsih, Muhammad Eko Atmojo, Muhammad Iqbal: the author analyzes the data and elaborates the relevant theoretical literature. The author is also actively involved in the formulation of research problems and adds a variety of relevant literature to strengthen the analysis and findings in the article.

\section{ACKNOWLEDGMENT}

Thank you to Universitas Muhammadiyah Yogyakarta

\section{REFERENCES}

[1] Sofyan, Riyanto, 2012, Prospek Bisnis Pariwisata Syariah, Jakarta: Buku Republika.

[2] Republika, 19 Juni 2017

[3] Republika, 28 Juli 2012

[4] Taylor, Frederick Winslow, 1978, The Principle of Scientific Management, New York: Herper \& Brother..

[5] Stoner, K. L. (2000). On Becoming Cuban: Identity, Nationality, and Culture. By Louis A. PérezJr..(Chapel Hill: University of North Carolina Press, 1999. Pp. xiv, 579. Illustrations. Map. Bibliography. Index. \$39.95.). The Americas, 57(1), 129-131.

[6] Bramwell, B, 2005, "Interventions and policy instruments for sustainable tourism", W.Theobold (Ed.), Global tourism (3rd ed., pp. 406-426). Oxford: Elsevier.

Kovjanic, G. (2014). "Islamic Tourism as a Factor of the Middle East Regional Development". Turizam, 18 (1), p. 33-43.

[8] Chookaew, S., Chanin, O., Charatarawat, J., Sriprasert, P., \& Nimpaya, S. (2015). Increasing halal tourism potential at Andaman Gulf in Thailand for Muslim country. Journal of Economics, Business and Management, 3(7), 739-741. 
[9] Kamarudin, L. M., \& Nizam, H. (2013, February). Islamic Tourism: The Impacts to Malaysia's Tourism Industry. In Proceedings of international conference on tourism development (pp. 397-405).

[10] Hotel, S. P., \& Duman, T. (2011). Value of Islamic Tourism Offering: Perspectives from the Turkish Experience.

[11] Henderson, J. C. (2010). Islam and tourism. In Tourism in the Muslim world. Emerald Group Publishing Limited.

[12] Ala-Hamarrneh, A., \& Steiner, C. (2004). Islamic tourism: Rethinking the strategies of tourism development in the Arab World after September 11, 2011. Comparative Studies of South East, 24(1), 173-182.

[13] Henderson, J. C. (2009). Islamic tourism reviewed. Tourism Recreation Research,34(2), 207-211.

[14] Shakıry, A. (2006). Religious Tourism: The pivot of tourism between Islamic countries and the attraction of Muslims world-wide. Islamic Tourism Prospects.

[15] Hassan, M. M., \& Shahnewaz, M. (2014). Measuring tourist service satisfaction at destination: A case study of Cox's Bazar sea beach, Bangladesh. American Journal of Tourism Management, 3(1), 32-43.

[16] Salleh, N. H. M., Othman, R., Noor, A. H. S. M., \& Hasim, M. S. (2010). Malaysian tourism demand from the Middle East market: A preliminary analysis. International Journal of West Asian Studies, 2(1).

[17] Gursoy, D., Chi, C. G., \& Dyer, P. (2010). Locals' attitudes toward mass and alternative tourism: The case of Sunshine Coast, Australia. Journal of Travel Research,49(3), 381-394.

[18] Kurniawan, Gilang Widagdo. 2015. Analisis Pasar Pariwisata Halal di Indonesia. The Journal of Tauhidinomics, Volume 1, Edisi 1.

[19] Pratiwi, A. E. (2016). Analisis pasar wisata syariah di kota yogyakarta. Media Wisata, 14(1).

[20] Awalia, H. (2017). Komodifikasi Pariwisata Halal NTB dalam Promosi Destinasi Wisata Islami di Indonesia. Jurnal Studi Komunikasi, 1(1), 19-30.
[21] Jaelani, A. (2017). Halal tourism industry in Indonesia: Potential and prospects. International Review of management and Marketing, 7(3).

[22] Putra, E. H., Hati, S. R. H., \& Daryantic, S. (2016, September). Understanding muslim customer satisfaction with halal destinations: The effects of traditional and islamic values. In International Conference on Business and Economics (pp. 167-175).

[23] Moleong, L. J. (2006). Metode penelitian kualitatif edisi revisi. Bandung: Remaja Rosdakarya. 